dr inż. Roman Żarnowski

prof. dr hab. inz. Omelian Plachtyna

mgr inz. Zbigniew Kłosowski

Uniwersytet Technologiczno-Przyrodniczy

w Bydgoszczy

\title{
O kształcie napięcia wyjściowego falownika pomocniczego pojazdu trakcyjnego na podstawie analizy $z$ wykorzystaniem wektora przestrzennego
}

\begin{abstract}
Wspótczesne układy elektryczne często sq zasilane ze źródet napięcia odksztatconego pochodzqcego z przeksztattników energoelektronicznych. Artykut jest opisem pracy pewnego nowego uktadu trójfazowego kaskadowego falownika napięcia z tróffazowym transformatorem, jako źródła napięcia bez wyższych harmonicznych do rzędu 10 wtacznie, lub $w$ wersji rozbudowanej bez harmonicznych do rzędu 22, na podstawie analizy z wykorzystaniem pojęcia wektora przestrzennego. Źródło trójfazowego napięcia o takiej jakości napięcia jest wystarczajace do zasilenia obwodów pomocniczych pradu przemiennego pojazdu trakcyjnego, jak imoże zasilać sieć autonomicznq, w tym silniki indukcyjne.
\end{abstract}

\section{Przedmiot rozważań}

Przedmiotem analizy są oryginalne układy z rysunków 1 i 2 przetwarzające napięcie stałe $w$ trójfazowe. Ponadto analizuje się kształt napięcia otrzymanego z tych układów w pracy jałowej i pod obciążeniem.

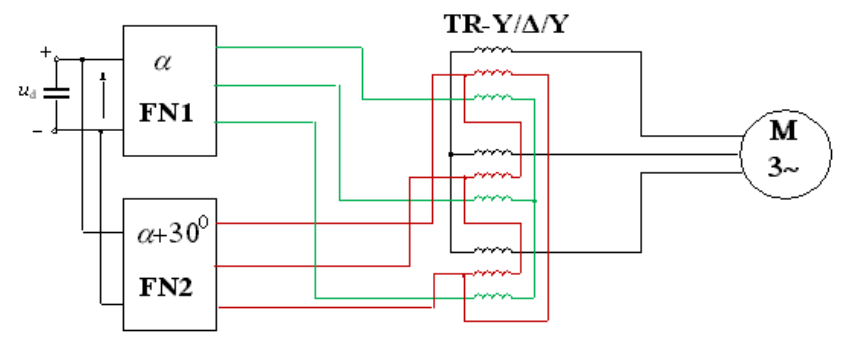

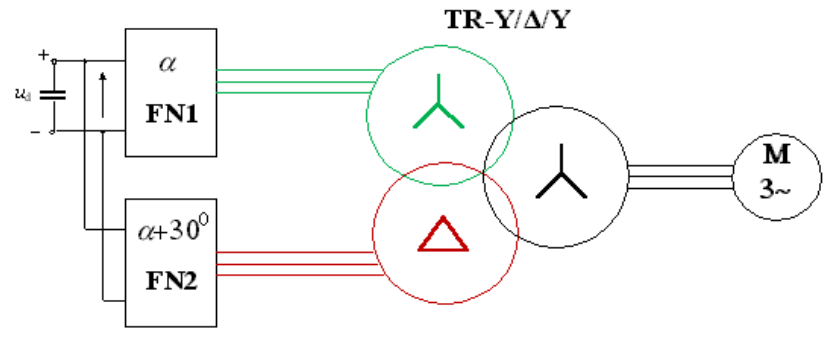

Rys.1. Schemat falownika kaskadowego

Dla celów dalszej analizy przekształtniki, które tu nazwano kaskadowymi, z rysunku 1 i 2 mogą zostać rozważone jako źródła 


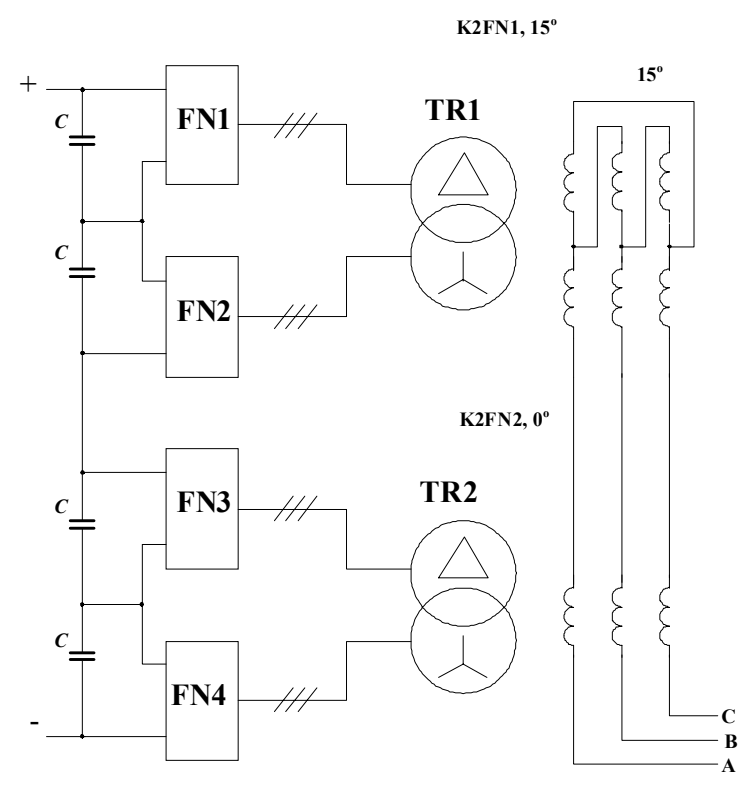

Rys. 2. Schemat falownika dwukaskadowego

zasilania w postaci szeregowo połączonych źródeł o różnych częstotliwościach, ułatwiając również ujęcie zagadnienia w konwencji wektora przestrzennego. Ta interpretacja wynika $\mathrm{z}$ faktu, że niesinusoidalne napięcia trójfazowego przekształtnika zostały rozłożone w szereg trygonometryczny Fourier'a. Rozłożenie sygnału na harmoniczne upraszcza analizę ponieważ występują składowe o stałych amplitudach i pulsacjach. Zamiast rozpatrywać zmienną amplitudę korzystniej rozpatrywać sumę wektorów wirujących zgodnie i przeciwnie. Ta analiza jest obarczona jednak pewnym ograniczeniem, mianowicie pracochłonnością oraz faktem, że nie odzwierciedla ona rzeczywistych procesów elektromagnetycznych $\mathrm{w}$ urządzeniach przekształcających. Metoda wektora przestrzennego ujmuje wielkości takie jak napięcia, prądy i strumienie skojarzone oraz przepływy $\mathrm{w}$ postaci jednego zapisu, we wszystkich możliwych stanach, a wyniki w postaci przebiegów czasowych otrzymuje się bezpośrednio. Wektor przestrzenny jest definiowany dla dowolnych sygnałów w czasie i jest odzwierciedleniem układu 3 napięć (prądów, strumieni, przepływów) o zgodnym lub przeciwnym następstwie faz.

W 3-fazowym układzie z rysunków 1 i 2 poddanym wymuszeniom niesinusoidalnym zachodzą związki, które tu uzasadniono.

\section{Wprowadzenie w zagadnienie}

Nawet przy pracy autonomicznej źródła musi być zachowana odpowiednia jakość parametrów energii elektrycznej, którą określają [3], takie jak:

a) wartość skuteczna napięcia (poziom napięcia),

b) częstotliwość,

c) kształt krzywej napięcia (zawartość wyższych harmonicznych określana współczynnikiem $T H D$ ),

d) symetria napięć trójfazowych.
Należy zwrócić uwagę, że w stanie pracy autonomicznej jakość energii zależy nie tylko od parametrów źródła, ale również od charakteru obciążenia. Nadmierne odchylenia napięcia od wartości znamionowej są niekorzystne zarówno ze względów gospodarczych, jak i technicznych. Powodują zmniejszenie sprawności urządzeń i wpływają na szybkość zużywania się tych urządzeń. W przypadku wytwarzania przez źródło napięcia odkształconego odbiorniki trzeba zasilać poprzez specjalne układy, poprawiające kształt fali napięcia, na przykład interfejsy sieciowe, filtry wyższych harmonicznych (szeregowe lub równoległe) lub kondycjonery $[7,9,10]$. Odkształcenie fali napięcia może powodować niepoprawną pracę niektórych urządzeń elektrycznych, przede wszystkim elektronicznych i energoelektronicznych ze sterowaniem fazowym, które do poprawnej pracy wymagają dokładnej detekcji przejścia fali napięcia przez zero.

Odkształcenie fali napięcia może być zdefiniowane na dwa sposoby [7]. W pierwszej metodzie zawartość wyższych harmonicznych określa się jako procent harmonicznej podstawowej. Sposób ten jest powszechnie stosowany w USA i Europie i zgodny jest z normą $[1,6]$. Całkowity współczynnik odkształcenia $T H D$ wyznacza się z zależności:

$$
T H D-F=\frac{\sqrt{\sum_{i=2}^{\infty} U_{\mathrm{i}}^{2}}}{U_{1}}
$$

Według niektórych ocen [7] zależność (1) wyolbrzymia problem wyższych harmonicznych. Alternatywna metoda przewiduje odniesienie wartości wyższych harmonicznych do wartości skutecznej napięcia:

$$
T H D-R=\frac{\sqrt{\sum_{i=2}^{\infty} U_{\mathrm{i}}^{2}}}{U}
$$

Zależność (2) jest wykorzystywana do obliczenia $T H D$ przez Canadian Standards Association i IEC. Polskie przepisy [1,6] przewidują obliczanie wartości $T H D$ według zależności (1). Nie powinna ona przekraczać $8 \%$, chociaż pożądane jest, aby była znacznie mniejsza. W przypadku występowania wyższych wartości tego współczynnika lub instalowania odbiorników wrażliwych na wyższe harmoniczne, może okazać się konieczne stosowanie filtrów wyższych harmonicznych

W przypadku, gdy źródło zawiera przekształtnik energoelektroniczny spełnienie wymagań dotyczących $T H D$ jest niewystarczające. W takim przypadku należy sprawdzić również poziomy poszczególnych wyższych harmonicznych, szczególnie w przypadku wykorzystywania w falowniku metody PWM $[1,2,6]$.

Zawartość wyższych harmonicznych w prądach silników indukcyjnych wywołuje momenty pasożytnicze, które są szczególnie dokuczliwe przy małych prędkościach silnika [8]. 
Tablica 1. Dopuszczalne wartości poszczególnych harmonicznych napięcia w zlączu sieci elektroenergetycznej dla rzędów do 25 wyrażone w procentach Uc wg [1]: Uc - deklarowane napięcie zasilające, zwykle równe napięciu znamionowemu UN sieci lub PCC (Point of Common Coupling).

\begin{tabular}{|c|c|c|c|c|c|}
\hline \multicolumn{4}{|c|}{ Harmoniczne nieparzyste } & \multirow{2}{*}{\multicolumn{2}{|c|}{$\begin{array}{l}\text { Harmoniczne } \\
\text { parzyste }\end{array}$}} \\
\hline \multicolumn{2}{|c|}{$\begin{array}{l}\text { Niebędace } \\
\text { krotnością } 3\end{array}$} & \multicolumn{2}{|c|}{$\begin{array}{l}\text { Będące } \\
\text { krotnością } 3\end{array}$} & & \\
\hline $\begin{array}{l}\text { Rząd } \\
\text { harm }\end{array}$ & $\begin{array}{l}\text { Wartość } \\
\text { względna } \\
\text { napięcia }\end{array}$ & $\begin{array}{l}\text { Rząd } \\
\text { harm }\end{array}$ & $\begin{array}{l}\text { Wartość } \\
\text { względna } \\
\text { napięcia }\end{array}$ & $\begin{array}{l}\text { Rząd } \\
\text { harm }\end{array}$ & $\begin{array}{l}\text { Wartość } \\
\text { względna } \\
\text { napięcia }\end{array}$ \\
\hline 5 & $6 \%$ & 3 & $5 \% *)$ & 2 & $2 \%$ \\
\hline 7 & $5 \%$ & 9 & $1,5 \%$ & 4 & $1 \%$ \\
\hline 11 & $3,5 \%$ & 15 & $0,5 \%$ & $6 \ldots 24$ & $0,5 \%$ \\
\hline 13 & $3 \%$ & 21 & $0,5 \%$ & & \\
\hline 17 & $2 \%$ & & & & \\
\hline 19 & $1,5 \%$ & & & & \\
\hline 23 & $1,5 \%$ & & & & \\
\hline 25 & $1,5 \%$ & & & & \\
\hline \multicolumn{6}{|c|}{$\begin{array}{l}\text { w zależności od układu sieci wartość trzeciej } \\
\text { harmonicznej może być znacząco mniejsza. }\end{array}$} \\
\hline \multicolumn{6}{|c|}{$\begin{array}{l}\text { UWAGA! Nie podano wartości harmonicznych o rzędach } \\
\text { większych niż } 25 \text {, ponieważ są one zwykle małe i w dużym } \\
\text { stopniu niemożliwe do przewidzenia ze względu na efekty } \\
\text { rezonansowe. }\end{array}$} \\
\hline
\end{tabular}

Dla wyższych harmonicznych silnik klatkowy pracuje w stanie bliskim zwarcia, zatem prąd, moment oraz straty nie zależą praktycznie od obciążenia [4]. Przy wyższych prędkościach obrotowych momenty wywołane wyższymi harmonicznymi są skutecznie tłumione przez bezwładność wirnika, mogą jednak powodować komplikacje przy rozruchu silnika [8].

\section{Analiza układu jednofazowego}

Aby przeanalizować przebieg napięcia wyjściowego układu $\mathrm{z}$ rysunku 1 rozważono najpierw zjawiska $\mathrm{w}$ transformatorze jednofazowym o budowie jak na rysunku 3, będącego odzwierciedleniem jednej kolumny transformatora trójfazowego.

Dla uproszczenia analizy pominięto spadki napięć na impedancjach zwarcia transformatora, które jednak zostaną uwzględnione $\mathrm{w}$ badaniach symulacyjnych układu głównego.

Uzwojenia takiego transformatora mogą być zasilane z falownika odpowiednikiem trójfazowego napięcia fazowego i napięcia przewodowego.

Jak wiadomo, strumień magnetyczny w kolumnie transformatora jest związany z napięciem zależnością: $u \approx e=-\frac{\mathrm{d} \Psi}{\mathrm{d} t}$, zatem wielkości te podlegają podobnym zmianom, a ściślej, pozostają z sobą w kofazie jeśli są sinusoidalne.

$$
\begin{gathered}
u_{1} \approx e_{1}=-\frac{\mathrm{d} \Psi_{1}}{\mathrm{~d} t}=-z_{1} \frac{\mathrm{d} \Phi}{\mathrm{d} t}, \\
u_{2} \approx e_{2}=-\frac{\mathrm{d} \Psi_{2}}{\mathrm{~d} t}=-z_{2} \frac{\mathrm{d} \Phi}{\mathrm{d} t}, \\
u \approx e=-\frac{\mathrm{d} \Psi}{\mathrm{d} t}=-z \frac{\mathrm{d} \Phi}{\mathrm{d} t} .
\end{gathered}
$$

Działając na tych równaniach matematycznie uzyskano:

$$
\frac{u_{1}}{z_{1}}+\frac{u_{2}}{z_{2}} \approx \frac{u}{z}
$$

Skąd: $u \approx \frac{z}{2 z_{1} z_{2}}\left(z_{2} u_{1}+z_{1} u_{2}\right)$.

Analizując prace jednej kolumny transformatora zasilanego z falownika trójfazowego można założyć, że napięciami wejściowymi transformatora $\mathrm{z}$ rys. 3 moga być odpowiednio napięcia: fazowe i napięcie przewodowe falownika trójfazowego podawane na transformator $\mathrm{z}$ odpowiednim przesunięciem fazowym fal napięcia w czasie, jak to pokazano na rysunku 3 .

W wymienionym przypadku napięcie $u_{1}$ po rozłożeniu w szereg Fouriera przedstawiono wyrażeniem (5), a rozłożone napięcie $u_{2}$ w szereg przedstawiono wyrażeniem (6):

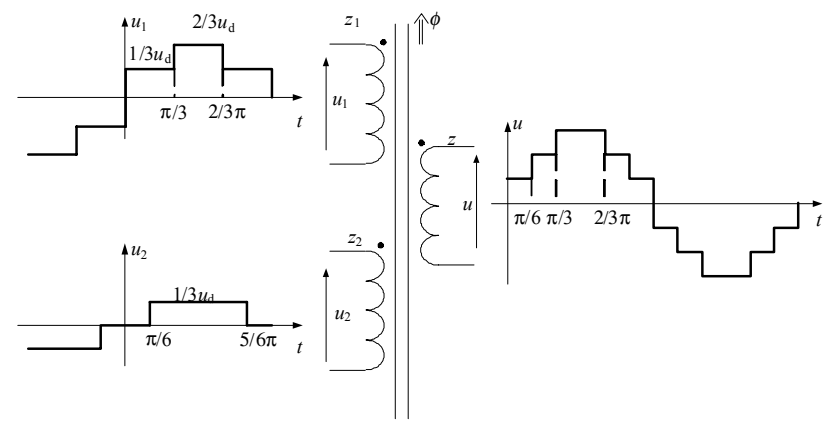

Rys 3. Transformator zasilany napięciami odkształconymi fazowym i przewodowym

$$
\begin{aligned}
& u_{1}=\frac{2 U_{\mathrm{d}}}{\pi}\left[\sin (\omega t)+\frac{1}{11} \sin (11 \omega t)+\right. \\
& +\frac{1}{13} \sin (13 \omega t)+\frac{1}{5} \sin (5 \omega t)+ \\
& \left.+\frac{1}{7} \sin (7 \omega t)+\frac{1}{17} \sin (17 \omega t)+\ldots\right] \\
& u_{1}=\frac{2 U_{\mathrm{d}} \sqrt{3}}{\pi}\left[\sin (\omega t)+\frac{1}{11} \sin (11 \omega t)+\right. \\
& +\frac{1}{13} \sin (13 \omega t)-\frac{1}{5} \sin (5 \omega t)+ \\
& \left.-\frac{1}{7} \sin (7 \omega t)-\frac{1}{17} \sin (17 \omega t)+\ldots\right]
\end{aligned}
$$


Jak wynika z zależności (4) kompensację 5. i 7. harmonicznej można przeprowadzić na dwa sposoby dobierając napięcia do jednakowej liczby zwojów, lub zwojność cewek do zadanych napięć. Stosunek wartości $\frac{z_{2} u_{1}}{z_{1} u_{2}}$ powinien wynosić 1 aby wystąpiła pełna kompensacja tych harmonicznych.

Powyższe równania otrzymano zakładając pracę jałową transformatora, a wpływ obciążenia uwzględniono w badaniach symulacyjnych.

\section{Uklad trójfazowy.}

Funkcje opisujące napięcie trójfazowe na wyjściu falownika zasilające transformator są przeważnie nieparzyste i antysymetryczne względem osi czasu, a suma przebiegów czasowych poszczególnych napięć jest równa zeru.

Ponieważ harmoniczne tworzą układy zgodne, przeciwne i zerowe wprowadza się następujące oznaczenie ich zbiorów:

$$
\begin{aligned}
& K=K^{+} \cup K^{-} \cup K^{0} \\
& \text { przy czym: } \\
& K^{+}=\{k, k=3 n+1, n=0,1,2,3, \ldots\}= \\
& =\{1,4,7,10,13, \ldots\} \\
& K^{-}=\{k, k=3 n-1, n=1,2,3,4, \ldots\}= \\
& =\{2,5,8,11,14, \ldots\} \\
& K^{0}=\{k, k=3 n, n=1,2,3,4, \ldots\}= \\
& =\{3,6,9,12,15, \ldots\} . \\
& \quad u_{\mathrm{U}}+u_{V}+u_{\mathrm{W}}=0 \\
& u_{\mathrm{U}}=\sum_{k=1}^{\infty} u_{\mathrm{mk}} \sin \left(k \omega t+\phi_{\mathrm{k}}\right) \\
& u_{\mathrm{V}}=\sum_{k=1}^{\infty} u_{\mathrm{mk}} \sin \left[k\left(\omega t-\frac{2}{3} \pi\right)+\phi_{\mathrm{k}}\right] \\
& u_{\mathrm{W}}=\sum_{k=1}^{\infty} u_{\mathrm{mk}} \sin \left[k\left(\omega t+\frac{2}{3} \pi\right)+\phi_{\mathrm{k}}\right]
\end{aligned}
$$

Równania dla poszczególnych faz przybierają wtedy postać

$$
\begin{aligned}
& u_{\mathrm{U}}=u_{+\mathrm{U}}+u_{-\mathrm{U}}+u_{0 \mathrm{U}} \\
& u_{\mathrm{V}}=u_{+\mathrm{V}}+u_{-\mathrm{V}}+u_{0 \mathrm{~V}} \\
& u_{\mathrm{W}}=u_{+\mathrm{W}}+u_{-\mathrm{W}}+u_{0 \mathrm{~W}}
\end{aligned}
$$

Wprowadzając wektor przestrzenny oznaczono:

$$
\begin{aligned}
& \underline{\mathrm{a}}=e^{\mathrm{j} \frac{2}{3} \pi} ; \underline{\mathrm{a}}^{-1}=\underline{\mathrm{a}}^{*}=\underline{\mathrm{a}}^{2}=e^{-\mathrm{j} \frac{2}{3} \pi} ; \\
& \underline{\mathrm{a}}=-\frac{1}{2}+\mathrm{j} \frac{\sqrt{3}}{2}
\end{aligned}
$$

Przy czym (") oznacza sprzężenie i zachodzi równość:

$$
\begin{aligned}
& 1+\underline{\mathrm{a}}+\underline{\mathrm{a}}^{2}=0 \\
& \widehat{\bigwedge}_{i, n \in \mathrm{N}} \underline{\mathrm{a}}^{3 n+i}=\underline{\mathrm{a}}^{i}
\end{aligned}
$$

Wektor przestrzenny układu trójfazowych napięć (11) wyznacza się z równości (15):

$$
\underline{\hat{\boldsymbol{u}}}=\frac{2}{3}\left[\begin{array}{lll}
1 & \underline{\mathrm{a}} & \underline{\mathrm{a}}^{2}
\end{array}\right]\left[\begin{array}{c}
u_{+\mathrm{U}}+u_{-\mathrm{U}}+u_{0 \mathrm{U}} \\
u_{+\mathrm{V}}+u_{-\mathrm{V}}+u_{0 \mathrm{~V}} \\
u_{+\mathrm{W}}+u_{-\mathrm{W}}+u_{0 \mathrm{~W}}
\end{array}\right]
$$

W równaniu (16) trzeci składnik sumy na mocy równości (13) jest równy zeru. Z równości (16) wynika, że harmoniczne rzędu $k=3 n, n=1,2,3,4 \ldots$ nie pozwalają ująć się w wyrażeniu wektora przestrzennego $\underline{\hat{\boldsymbol{u}}} \mathrm{i}$ w koniecznych przypadkach należy je uwzględniać oddzielnie

$$
\begin{aligned}
& \underline{\hat{\boldsymbol{u}}}=\frac{2}{3}\left[\begin{array}{lll}
1 & \underline{\mathrm{a}} & \underline{\mathrm{a}}^{2}
\end{array}\right]\left[\begin{array}{l}
u_{+\mathrm{U}} \\
u_{+\mathrm{V}} \\
u_{+\mathrm{W}}
\end{array}\right]+\frac{2}{3}\left[\begin{array}{lll}
1 & \underline{\mathrm{a}} & \underline{\mathrm{a}}^{2}
\end{array}\right]\left[\begin{array}{l}
u_{-\mathrm{U}} \\
u_{-\mathrm{V}} \\
u_{-\mathrm{W}}
\end{array}\right]+ \\
& +\frac{2}{3}\left[\begin{array}{lll}
1 & \underline{\mathrm{a}} & \underline{\mathrm{a}}^{2}
\end{array}\right]\left[\begin{array}{l}
u_{0 \mathrm{U}} \\
u_{0 \mathrm{~V}} \\
u_{0 \mathrm{~W}}
\end{array}\right]
\end{aligned}
$$

W najczęściej spotykanych układach falowników (i tu rozważanym) nie stosuje się przewodu neutralnego. Wtedy równanie (17) jest słuszne bez dodatkowych założeń. Ponieważ przekształcenie układu napięć trójfazowych do wektora przestrzennego zaciera informację o harmonicznych ze zbioru $K^{0}$, dlatego w przekształceniu odwrotnym te składowe w układach czteroprzewodowych lub transformatorach pięciokolumnowych, w których może wystapić składowa zerowa strumienia należy przywrócić bezpośrednio jak w równaniu (19).

Zachodzi równość:

$$
\begin{aligned}
& \underline{\hat{\boldsymbol{u}}}=\underline{\hat{\boldsymbol{u}}}_{+}-\underline{\hat{\boldsymbol{u}}}_{-}+\underline{\hat{\boldsymbol{u}}}_{0}=\underline{\hat{\boldsymbol{u}}}_{+}-\underline{\hat{\boldsymbol{u}}}_{-}, \\
& \text {w której: } \quad \underline{\hat{\boldsymbol{u}}}_{+}=\sum_{k \in K^{+}}^{\infty} u_{\mathrm{mk}} e^{\mathrm{j}\left(k \omega t+\phi_{k}\right)} \\
& \underline{\hat{\boldsymbol{u}}}_{-}=\sum_{k \in K^{-}}^{\infty} u_{\mathrm{mk}} e^{-\mathrm{j}\left(k \omega t+\phi_{k}\right)} \\
& \underline{u}_{\mathrm{U}}(t)=u_{0}+\operatorname{Im}\left(\underline{\hat{\boldsymbol{u}}}_{+}\right)-\operatorname{Im}\left(\underline{\hat{\boldsymbol{u}}}_{-}^{*}\right) \\
& \underline{u}_{\mathrm{V}}(t)=u_{0}+\operatorname{Im}\left(\underline{\mathrm{a}}^{2} \underline{\hat{\boldsymbol{u}}}_{+}\right)-\operatorname{Im}\left(\underline{\mathrm{a}}_{\hat{\boldsymbol{u}}_{-}^{*}}\right) \\
& \underline{u}_{\mathrm{W}}(t)=u_{0}+\operatorname{Im}\left(\underline{\mathrm{a}}_{\hat{\boldsymbol{u}}}\right)-\operatorname{Im}\left(\underline{\mathrm{a}}^{2} \underline{\hat{\boldsymbol{u}}}_{-}^{*}\right)
\end{aligned}
$$

Zapis wektora przestrzennego w równaniu (15) jest konsekwencją założenia, że oś Realis płaszczyzny Gaussa pokrywa się ze wskazem napięcia fazy A to jest napięcia $u_{\mathrm{A}}$, a wynikiem przekształcenia będą funkcje postaci $\mathrm{f}(t)=\cos \omega t \pm j \operatorname{jin} \omega t$. Zwykle harmoniczne wyraża się za pomocą funkcji sinus, dlatego wystarczy wziąć część urojoną wyrażenia, $\operatorname{Im}(\mathrm{f}(t))$, aby otrzymać postać czasową harmonicznej (19). 
Analiza pracy układu trójfazowego kaskadowego falownika napięcia (Rys. 1.)

Powyżej napisane jest już częściowo znane z literatury $[4,7,8,9]$, jednak przytoczono te równania dla jasności dalszego wywodu. Aby sformalizować rozważania wprowadza się zespoloną przekładnię transformatora trójfazowego, która w wyniku działania mnożenia pozwoli przekształcić szereg opisujący napięcie pierwotne w szereg opisujący napięcie wtórne transformatora. Przekładna zespolona przedstawia się jako $\underline{K}_{\mathrm{T}}=\frac{\underline{u}_{\mathrm{p}}}{\underline{u}_{\mathrm{s}}}=K_{\mathrm{T}} e^{\mathrm{j} \vartheta}$, a wektor przestrzenny

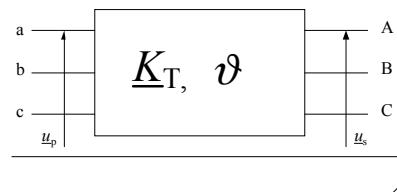

Rys. 4. Symboliczne przedstawienie transformatora z przekładnią zespoloną

Należy przy tym zauważyć, że wektory przestrzenne $\underline{\hat{\boldsymbol{u}}}_{\mathrm{p}+} \quad \mathrm{i} \quad \underline{\hat{\boldsymbol{u}}}_{\mathrm{P}-}^{*}$ zawierają już zakodowane znaki harmonicznych.

Pierwotne napięcie uzwojenia połączonego $\mathrm{w}$ gwiazdę zgodnie z warunkiem (4) i założeniem, że uzwojenia pierwotne gwiazdy i wtórne gwiazdy leżą na tych samych kolumnach i są ze sobą w fazie, transformuje się z przekładnią $K_{\mathrm{TY}}=1$. (układ yY0; napięcia odniesiono do wspólnego uzwojenia wtórnego oznaczonego literą „Y”) Drugie napięcie pierwotne, uzwojenia połączonego $\mathrm{w}$ trójkąt na podstawie tych samych warunków transformuje się $\mathrm{z}$ przekładnią $K_{\mathrm{TD}}=\frac{1}{\sqrt{3}} e^{\mathrm{j} \frac{\pi}{6}}$, a więc z opóźnieniem o kąt $\frac{\pi}{6}(\mathrm{układ}$ dY11).

Wektor przestrzenny łącznego napięcia wyjściowego jest dany równaniem (21): $\underline{\hat{\boldsymbol{u}}}=\underline{\hat{\boldsymbol{u}}_{\mathrm{Y}}}+\underline{\hat{\boldsymbol{u}}_{\mathrm{D}}}$

przy czym:

$\underline{\hat{\boldsymbol{u}}}_{\mathrm{Y}}=\underline{K}_{\mathrm{TY}}\left(\hat{\boldsymbol{u}}_{\mathrm{Yp}+}-\underline{\hat{\boldsymbol{u}}}_{\mathrm{Yp}-}^{*}\right)$

oznacza przetransformowane napięcie gwiazdy,

$\underline{\hat{\boldsymbol{u}}_{\mathrm{D}}}=\underline{K}_{\mathrm{TD}}\left(\hat{\boldsymbol{u}}_{\mathrm{Dp}+}-\underline{\hat{\boldsymbol{\mu}}}_{\mathrm{DP}-}^{*}\right)$

oznacza przetransformowane napięcie trójkąta.

Przetransformowane napięcie gwiazdy, liczone po zbiorach $K^{+}{ }_{i}$ $K^{-}$dla rozważanego układu wynosi (23)

$$
K^{+}=\{1,7,13,19 \ldots\} \quad \text { i } \quad K^{-}=\{5,11,17, \ldots\}
$$

$$
\begin{aligned}
\underline{\hat{\boldsymbol{u}}_{\mathrm{Y}}} & =\frac{2 U_{\mathrm{d}}}{\pi}\left[\sum_{\mathrm{K}^{+}}^{\infty} \frac{1}{k} e^{\mathrm{j} k \omega t}-\sum_{\mathrm{K}^{-}}^{\infty} \frac{1}{k} e^{-\mathrm{j} k \omega t}\right]= \\
= & \frac{2 U_{\mathrm{d}}}{\pi}\left[e^{\mathrm{j} \omega t}+\frac{1}{7} e^{\mathrm{j} 7 \omega t}+\frac{1}{13} e^{\mathrm{j} 13 \omega t}+\frac{1}{19} e^{\mathrm{j} 19 \omega t}+\ldots+\right. \\
& \left.-\left(\frac{1}{5} e^{-\mathrm{j} 5 \omega t}+\frac{1}{11} e^{-\mathrm{j} 11 \omega t}+\frac{1}{17} e^{-\mathrm{j} 11 \omega t}+\ldots\right)\right]
\end{aligned}
$$

W przypadku połączenia w trójkąt pierwsza harmoniczna przetransformowanego napięcia uzwojenia wyprzedza o $\frac{\pi}{6}$ przetransformowane napięcie pierwszej harmonicznej uzwojenia połączonego w gwiazdę. O ten sam kąt szybciej wyzwalane są łączniki falownika napięcia FN2. W zapisie harmonicznych kąt wysterowania łączników ujawnia się w wykładniku wektora przestrzennego i podlega mnożeniu przez rząd harmonicznej. Oznacza to że harmoniczna rzędu $k$ wyprzedza pierwszą harmoniczną wynikowego napięcia o kąt $k \frac{\pi}{6}$. Przetransformowane napięcie trójkąta, z uwzględnieniem warunku (5), dane jest wyrażeniem (24). Zsumowanie napięć, (które w transformatorze odbywa się poprzez sumowanie przepływów) we wtórnym uzwojeniu połączonym w gwiazdę, na podstawie równań (21) oraz (23) i (24) przynosi wynik, który można ująć zależnością:

$$
\begin{aligned}
& \underline{\hat{\boldsymbol{u}}_{\mathrm{D}}}=\frac{2 \sqrt{3} U_{\mathrm{d}}}{\sqrt{3} \pi} e^{\mathrm{j} \frac{\pi}{6}}\left[\sum_{\mathrm{K}^{+}}^{\infty} \frac{1}{k} e^{\mathrm{j}\left[k\left(\omega t-\frac{\pi}{6}\right)\right]}-\sum_{\mathrm{K}^{-}}^{\infty} \frac{1}{k} e^{-\mathrm{j}\left[k\left(\omega t-\frac{\pi}{6}\right)\right]}\right]= \\
& =\frac{2 U_{\mathrm{d}}}{\pi} e^{\mathrm{j} \frac{\pi}{6}}\left[e^{\mathrm{j}\left(\omega t-\frac{\pi}{6}\right)}+\frac{1}{7} e^{\mathrm{j} 7\left(\omega t-\frac{\pi}{6}\right)}+\frac{1}{13} e^{\mathrm{j} 13\left(\omega t-\frac{\pi}{6}\right)}+\right. \\
& \left.+\frac{1}{19} e^{\mathrm{j} 19\left(\omega t-\frac{\pi}{6}\right)}+\ldots\right)-\left(\frac{1}{5} e^{-\mathrm{j} j\left(\omega t-\frac{\pi}{6}\right)}+\frac{1}{11} e^{-\mathrm{j} 11\left(\omega t-\frac{\pi}{6}\right)}+\right. \\
& \left.\left.+\frac{1}{17} e^{-\mathrm{j} 17\left(\omega t-\frac{\pi}{6}\right)}+\ldots\right)\right]= \\
& =\frac{2 U_{\mathrm{d}}}{\pi}\left[e^{\mathrm{j} \omega t}+\frac{1}{7} e^{\mathrm{j}(7 \omega t-\pi)}+\frac{1}{13} e^{\mathrm{j}(13 \omega t-12 \pi)}+\right. \\
& +\frac{1}{19} e^{\mathrm{j}\left(19 \omega t-\frac{18 \pi}{6}\right)}+\ldots-\frac{1}{5} e^{-\mathrm{j}\left[\left(5 \omega t-\frac{6 \pi}{6}\right)\right]}+ \\
& \left.-\frac{1}{11} e^{-\mathrm{j}\left[\left(11 \omega t-\frac{12 \pi}{6}\right)\right]}-\frac{1}{17} e^{-\mathrm{j}\left[\left(17 \omega t-\frac{18 \pi}{6}\right)\right]}+\ldots\right]= \\
& =\frac{2 U_{\mathrm{d}}}{\pi}\left[e^{\mathrm{j} \omega t}-\frac{1}{7} e^{\mathrm{j} 7 \omega t}+\frac{1}{13} e^{\mathrm{j} 13 \omega t}+\right. \\
& -\frac{1}{19} e^{\mathrm{j} 19 \omega t}+\ldots+\frac{1}{5} e^{-\mathrm{j} 5 \omega t}-\frac{1}{11} e^{-\mathrm{j} 11 \omega t}+ \\
& \left.+\frac{1}{17} e^{-\mathrm{j} 17 \omega t}+\ldots\right]
\end{aligned}
$$




$$
\begin{aligned}
& \underline{\hat{\boldsymbol{u}}}=\frac{2 U_{\mathrm{d}}}{\pi}\left[e^{\mathrm{j} \omega t}-\frac{2}{11} e^{-\mathrm{j} 11 \omega t}+\frac{2}{13} e^{\mathrm{j} 13 \omega t}+\right. \\
& \left.-\frac{2}{23} e^{-\mathrm{j} 23 \omega t}+\frac{2}{25} e^{\mathrm{j} 25 \omega t}+\ldots\right]
\end{aligned}
$$

W napięciu wyjściowym transformatora wystapią harmoniczne 1., 11., 13., i 23., 25., i zgodnie $\mathrm{z}$ pierwszym równaniem zależności (19) dla fazy A można napisać szereg:

$$
\begin{aligned}
& u_{\mathrm{A}}=\frac{2 U_{\mathrm{d}}}{\pi}\left[\sin \omega t-\frac{2}{11} \sin (11 \omega t)+\right. \\
& +\frac{2}{13} \sin (13 \omega t)-\frac{2}{23} \sin (23 \omega t)+ \\
& \left.+\frac{2}{25} \sin (25 \omega t)+\ldots\right] .
\end{aligned}
$$

Kształt napięcia wyjściowego transformatora $\mathrm{z}$ rys.1 zmieni się pod wpływem obciążenia. Ten stan jest analizowany symulacyjnie na rysunkach Rys. $5 . \div 13$.

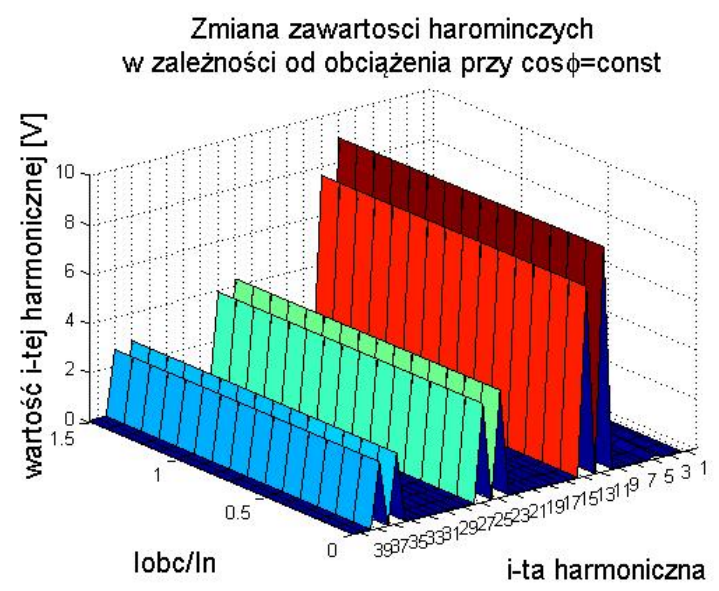

Rys. 5. Zmiana zawartości harmonicznych w zależności od obciążenia układu przy $\cos \varphi_{\text {ind }}=0,8$ (schemat z Rys. 1)

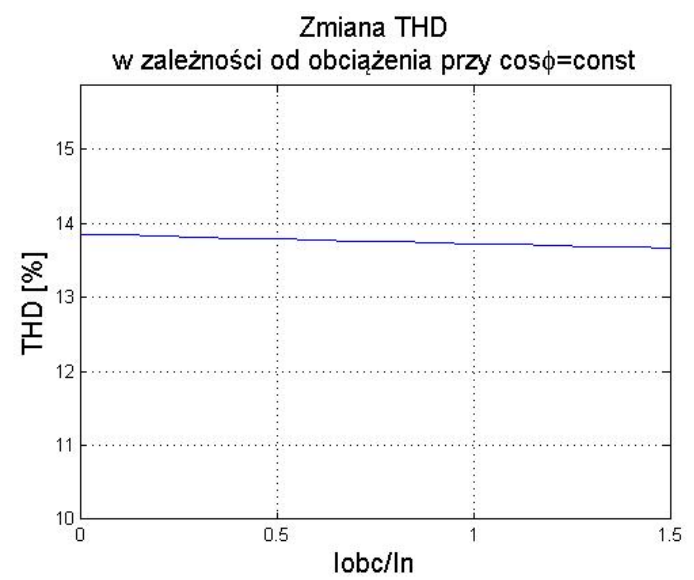

Rys. 6. Zmiana zawartości harmonicznych w zależności od obciażenia układu przy $\cos \varphi_{\text {ind }}=0,8$ mierzona współczynnikiem THD (schemat z Rys. 1)
W przypadku obciążenia indukcyjnego o $\cos \varphi_{\text {ind }}=0,8$ zawartość harmonicznych nie zmienia się znacząco. W liniowym transformatorze nie występują harmoniczne 3. i jej wielokrotne, a współczynnik THD osiaga wartość około $14 \%$.

Symulacje wykazały, że przy obciążeniu rezystancyjnym układu te zmiany są bardziej istotne. W miarę obciążania układu współczynnik THD maleje, a swoją najwyższą wartość osiaga na biegu jałowym układu.

Ze wspomnianych powodów, przy założeniu, że transformator jest urządzeniem nieliniowym pojawiają się znacznej wartości harmoniczne, które nie występują w układzie liniowym. Jednakże te harmoniczne pojawiają się niezależnie od immanentnych cech proponowanego układu wykluczającego ich powstawanie.

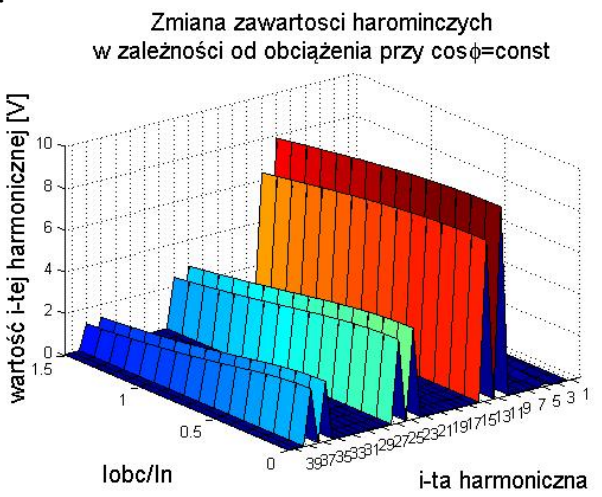

Rys. 7. Zmiana zawartości harmonicznych w zależności od obciążenia układu przy $\cos \varphi=1,0$ (schemat z Rys. 1)

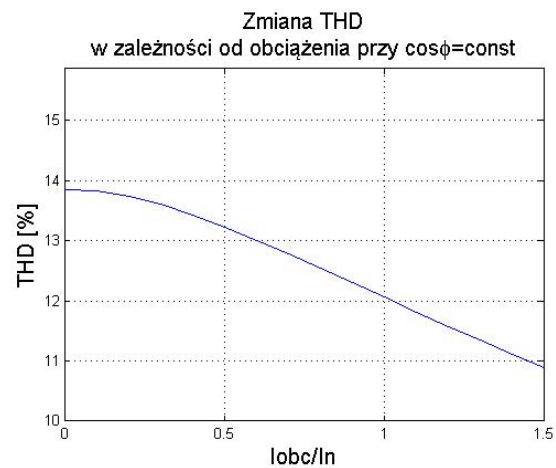

Rys. 8. Zmiana zawartości harmonicznych w zależności od obciążenia układu przy $\cos \varphi=1,0$ mierzona współczynnikiem THD (schemat z Rys. 1)

Zmiana zawartosci harominczych w zależności od obciążenia przy $\cos \phi=$ const

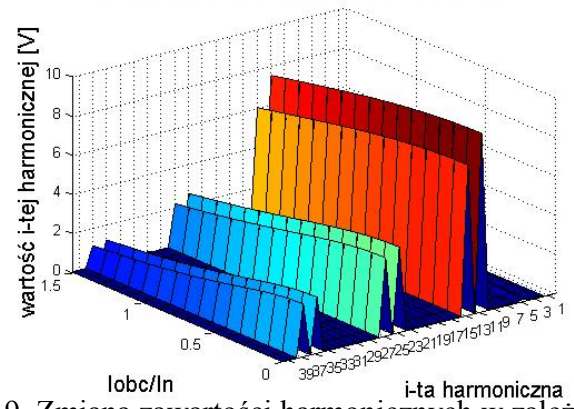

Rys. 9. Zmiana zawartości harmonicznych w zależności od obciążenia układu przy $\cos \varphi_{\text {poj }}=0,9$ (schemat z Rys. 1) 
Zmiana THD

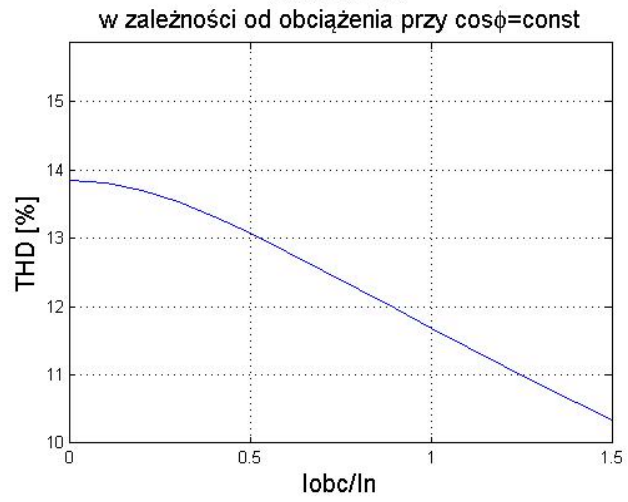

Rys. 10. Zmiana zawartości harmonicznych w zależności od obciążenia układu przy $\cos \varphi_{\text {poj }}=0,9$ mierzona współczynnikiem THD (schemat z Rys. 1)

Ten stan zilustrowano na rysunkach Rys. 11 i Rys. 12. Zmiana zawartosci harominczych w zależności od obciążenia przy $\cos \phi=$ const

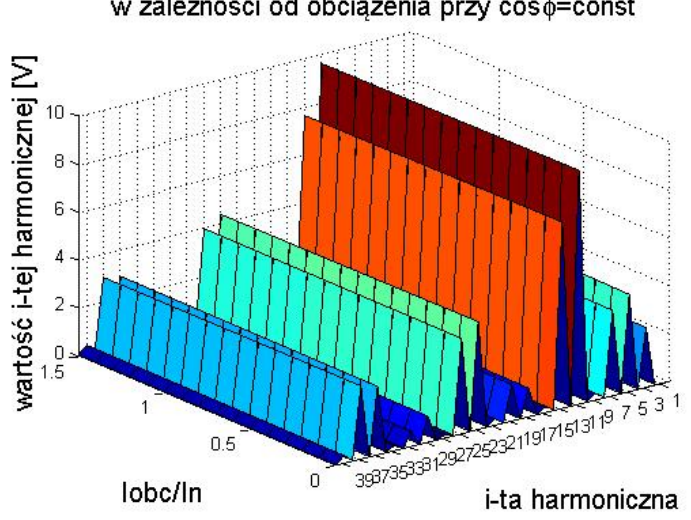

Rys. 11. Zmiana zawartości harmonicznych w zależności od obciążenia układu przy $\cos \varphi_{\text {ind }}=0,8$ (schemat z Rys. 1)

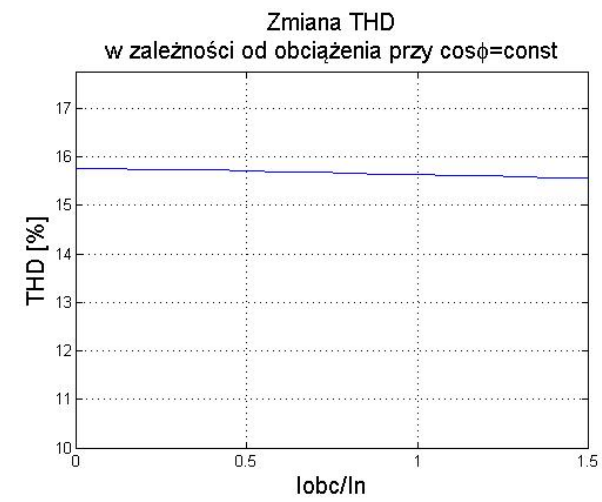

Rys. 12. Zmiana zawartości harmonicznych w zależności od obciążenia układu przy $\cos \varphi_{\text {ind }}=0,8$ mierzona współczynnikiem THD (schemat z Rys. 1)

\section{Analiza pracy układu trójfazowego dwukaskado wego falownika napięcia (Rys. 2.)}

Zgodnie $\mathrm{z}$ teorią przedstawioną $\mathrm{w}$ [5] łącząc $\mathrm{w}$ odpowiedni sposób falowniki kaskadowe $\mathrm{w}$ falowniki dwu i więcej kaskadowe można $\mathrm{z}$ napięcia wyjściowego takiego falownika wielokaskadowego wyeliminować kolejne harmoniczne, to jest 11. i $13 .$. Egzemplifikacją takiego falownika jest ten $\mathrm{z}$ rysunku
2. Analizując widmo harmonicznych w jego napięciu wyjściowym można napisać dwie składowe tego napięcia: składową napięcia przetransformowaną do uzwojenia połączonego $\mathrm{w}$ przedłużony trójkąt i drugą składową napięcia przetransformowaną do uzwojenia połączonego $\mathrm{w}$ gwiazdę. Zakłada się przy tym, że przedłużony trójkąt wnosi półgodzinne wyprzedzenie fazowe. Napięcie układu przedłużonego trójkąta może być rozważane jak napięcie układu gwiazdy, przy czym wyzwalanie tranzystorów kaskady zasilającej go musi również opóźniać się względem momentu wyzwalania kaskady zasilającej uzwojenie przedłużonego trójkąta o ten sam kąt, to jest o $\frac{\pi}{12}$. Zgodnie z zasada wzmiankowaną powyżej wyprzedzenie czasowe wnosi się do wykładnika wektora przestrzennego napięcia przedłużonego trójkąta danego teraz przez zależność (25), a po przemnożeniu przez przekładnię zespoloną $K_{\mathrm{T}}=e^{\mathrm{j} \frac{\pi}{12}}$ otrzymuje się napięcie na wyjściu przedłużonego trójkąta jako:

$$
\begin{aligned}
& \frac{\hat{\boldsymbol{u}}_{\mathrm{D}_{\mathrm{Y}}}}{=}=\frac{2 U_{\mathrm{d}}}{\pi} e^{\mathrm{j} \frac{\pi}{12}}\left[e^{\mathrm{j}\left(\omega t-\frac{\pi}{12}\right)}-\frac{2}{11} e^{-\mathrm{j} 11\left(\omega t-\frac{\pi}{12}\right)}+\right. \\
& \left.+\frac{2}{13} e^{\mathrm{j} 13\left(\omega t-\frac{\pi}{12}\right)}-\frac{2}{23} e^{-\mathrm{j} 23\left(\omega t-\frac{\pi}{12}\right)}+\frac{2}{25} e^{\mathrm{j} 25\left(\omega t-\frac{\pi}{12}\right)}+\ldots\right]
\end{aligned}
$$

Napięcie części wtórnej układu połączonej w gwiazdę jest dane zależnością (25) uzasadnioną powyżej.

$$
\begin{aligned}
\underline{\hat{\boldsymbol{u}}_{\mathrm{Y}}} & =\frac{2 U_{\mathrm{d}}}{\pi}\left[e^{\mathrm{j} \omega t}-\frac{2}{11} e^{-\mathrm{j} 11 \omega t}+\frac{2}{13} e^{\mathrm{j} 13 \omega t}+\right. \\
& \left.-\frac{2}{23} e^{-\mathrm{j} 23 \omega t}+\frac{2}{25} e^{\mathrm{j} 25 \omega t}+\ldots\right]
\end{aligned}
$$

Sumowanie tych napięć przynosi wynik:

$$
\begin{aligned}
& \frac{\hat{\boldsymbol{u}}_{\mathrm{D}_{\mathrm{Y}} \mathrm{Y}}}{\left.\frac{4}{25} e^{\mathrm{j} 25 \omega t}+\ldots\right]} \underline{\hat{\boldsymbol{u}}_{\mathrm{D}_{\mathrm{Y}}}}+\underline{\hat{\boldsymbol{u}}_{\mathrm{Y}}}=\frac{2 U_{\mathrm{d}}}{\pi}\left[2 e^{\mathrm{j} \omega t}-\frac{4}{23} e^{-\mathrm{j} 23 \omega t}+\right.
\end{aligned}
$$

\section{Wnioski}

Powyższe oznacza, że najbliższymi wyższymi harmonicznymi w takim układzie są 23 i 25 . Układ może więc pełnić rolę pomocniczego źródła napięcia na pojeździe trakcyjnym, lub źródła autonomicznej sieci o korzystnym kształcie napięcia, a współczynnik $T H D$ wynosi wtedy około $6 \%$. 


\section{Literatura}

[1] Norma PN-EN 50160: grudzień 2002

[2] Lubośny Z.: Elektrownie wiatrowe $w$ systemie elektroenergetycznym, WNT, Warszawa 2006

[3] Markiewicz H.: Instalacje elektryczne. WNT, Warszawa 2005, wyd. VI

[4] Mohan N., Electric drives. MNPERE, Minneapolis 2001

[5] Ptachtyna E.: Matematiczeskoje modelirowanie elektro-maszinno-wentilnych sytem. Izdatielstwo „,Wyższa Szkoła”, Lwów 1986

[6] Markiewicz H. Klajn A. Norma PEN 50160. Parametry napięcia zasilajacego $w$ publicznych sieciach rozdzielczych $w$ Podręcznik INPE dla elektryków, zeszyt 6, Jakość energii elektrycznej. Europejski program LPQI. Wydawnictwa SEPCOSiW, Warszawa 2005

[7] Skvarenina T. L.: The Power Electronics Handbook. Industrial Electronics Series CRC Press. Washington 2000

[8] Kaźmierkowski M. P.: Automatic Control of Converter-Fed Drives. Elsevier Publisher, AmsterdamLondon-New York-Tokyo 1994

[9] Halpin S. M., Card A.: Power Quality [in:] Power Electronics Handbook, Rashid M. H. (Editor-inChieff), Academic Press 2001

[10] Strzelecki R., Supronowicz H.: Filtracja harmonicznych $w$ sieciach zasilajacych pradu przemiennego. Wyd. A. Marszatek, Toruń 1999
Autorzy: dr inż. Roman Żarnowski, Uniwersytet Technologiczno-Przyrodniczy, Instytut Elektrotechniki, Zakład Energoelektroniki Maszyn i Napędów Elektrycznych, Al. Prof. S. Kaliskiego 7, 85-796 Bydgoszcz, E-mail: zarnow-ski@utp.edu.pl, prof. dr hab. inż. Omelian Płachtyna, Uniwersytet TechnologicznoPrzyrodniczy Instytut Elektrotechniki, Zakład Energoelektroniki Maszyn i Napędów Elektrycznych, Al. Prof. S. Kaliskiego 7, 85-796 Bydgoszcz, E-mail: plakht@utp.edu.pl; mgr inż. Zbigniew Kłosowski, Uniwersytet Technologiczno-Przyrodniczy, Instytut Elektro-techniki, Zakład Elektroenergetyki, Al. Prof. S. Kaliskiego 7, 85-796 Bydgoszcz, E-mail: klosowski@utp.edu.pl. 